CLINICAL STUDY

\title{
Diagnosis of subclinical central hypothyroidism in patients with hypothalamic-pituitary disease by Doppler echocardiography
}

\author{
Fabio Casanova Doin ${ }^{1}$, Mariana Rosa-Borges ${ }^{2}$, Manoel R A Martins ${ }^{2}$, Valdir A Moisés ${ }^{1}$ and Julio Abucham ${ }^{2}$ \\ ${ }^{1}$ Cardiology Division, Escola Paulista de Medicina, Universidade Federal de São Paulo, São Paulo, Brazil and ${ }^{2}$ Neuroendocrine Unit, Endocrinology Division, \\ Escola Paulista de Medicina, Universidade Federal de São Paulo, Rua Pedro de Toledo 910, 04039-002 São Paulo, Brazil
}

(Correspondence should be addressed to J Abucham; Email: julioabucham@uol.com.br)

\begin{abstract}
Objective: The diagnosis of subclinical central hypothyroidism in hypothalamic-pituitary patients cannot be established by serum markers of thyroid hormone action. Myocardial function by echocardiography has been shown to reflect thyroid hormone action in primary thyroid dysfunction. We evaluated the performance of echocardiography in diagnosing subclinical central hypothyroidism. Design: Cross-sectional and before and after.

Methods: Echocardiography and serum thyroid hormones were assessed in overt primary $(n=20)$ and central $(n=10)$ hypothyroidism, subclinical primary hypothyroidism $(n=10)$, hypothalamic-pituitary disease with normal free thyroxine $\left(\mathrm{FT}_{4} ; n=25\right)$, and controls $(n=28)$. Receiver operating characteristic (ROC) curves were generated using overt hypothyroidism patients and selected cut-off values were applied to detect both primary and central subclinical hypothyroidism. After levothyroxine $\left(\mathrm{L}-\mathrm{T}_{4}\right)$ intervention, patients were echocardiographically reevaluated at predefined targets: normal thyrotropin (TSH) in primary hypothyroidism, normal $\mathrm{FT}_{4}$ in overt central hypothyroidism, and higher than pretreatment $\mathrm{FT}_{4}$ in echo-defined subclinical central hypothyroidism.

Results: Parameters with highest areas under the ROC curves (area under the curve (AUC) $\geq 0.94$ ) were as follows: isovolumic contraction time (ICT), ICT/ejection time (ET), and myocardial performance index. Highest diagnostic accuracy (93\%) was obtained when at least one parameter was increased (positive and negative predictive values: 93\%). Hypothyroidism was echocardiographically diagnosed in eight of ten patients with subclinical primary hypothyroidism and in 14 of 25 patients $(56 \%)$ with hypothalamic-pituitary disease and normal serum $\mathrm{FT}_{4}$. Echocardiographic abnormalities improved significantly after $\mathrm{L}-\mathrm{T}_{4}$ and correlated $(0.05<P<0.001)$ with changes in $\mathrm{FT}_{4}$ $(-0.62<r<-0.55)$ and TSH $(0.63<r<0.68)$ in primary hypothyroidism and with $\mathrm{FT}_{4}$ in central hypothyroidism $(-0.72<r<-0.50)$.

Conclusion: Echocardiography can be useful in diagnosing subclinical central hypothyroidism in patients with hypothalamic-pituitary disease.
\end{abstract}

European Journal of Endocrinology 166 631-640

\section{Introduction}

Central hypothyroidism is a frequent disorder in patients with hypothalamic-pituitary disease. It results from decreased stimulation of an otherwise normal thyroid gland by a decreased and/or biologically less active thyrotropin (TSH) $(1,2)$. Risk factors for central hypothyroidism include large sellar lesions, previous surgery, radiotherapy, and other pituitary hormone deficiencies. In practice, the diagnosis of central hypothyroidism relies on a low serum free thyroxine $\left(\mathrm{FT}_{4}\right)$ with decreased, normal, or slightly elevated serum TSH (3). However, a low serum $\mathrm{FT}_{4}$ is a highly specific but insensitive marker of hypothyroidism, whereas several serum markers of thyroid hormone action and the response of TSH to its releasing hormone have shown low diagnostic sensitivity $(4,5)$.
The cardiovascular system is a major target of thyroid hormone, which influences cardiac function both directly and indirectly via changes in peripheral vascular resistance and circulating volume (6). Noninvasive evaluation of myocardial function, both in animals and humans, has shown opposite abnormalities in systolic time intervals in primary hypothyroidism and hyperthyroidism that can be reversed by appropriate therapy $(7,8,9)$. In primary hypothyroidism, systolic time intervals are typically lengthened and decreased after $\mathrm{T}_{4}$ replacement in correlation with changes in thyroid hormones (10).

Formerly, assessment of systolic intervals was cumbersome, involving simultaneous recordings of electrocardiogram, phonocardiogram, and carotid pulse tracing (11). Currently, Doppler echocardiography is a simple and widely available method that allows 
Table 1 Baseline clinical and hormonal characteristics of controls and patients with overt primary hypothyroidism, overt central hypothyroidism, subclinical primary hypothyroidism, and hypothalamic-pituitary disease with normal $\mathrm{FT}_{4}$ levels. Plus-minus values are means \pm S.D.

\begin{tabular}{|c|c|c|c|c|c|c|}
\hline & $\begin{array}{c}\text { Controls } \\
(n=28)\end{array}$ & $\begin{array}{c}\text { Overt primary } \\
\text { hypothyroidism } \\
(n=20)\end{array}$ & $\begin{array}{c}\text { Overt central } \\
\text { hypothyroidism } \\
(n=10)\end{array}$ & $\begin{array}{c}\text { Subclinical } \\
\text { primary } \\
\text { hypothyroidism } \\
(n=10)\end{array}$ & $\begin{array}{l}\text { Hypothalamic- } \\
\text { pituitary normal } \\
\mathrm{FT}_{4}(n=25)\end{array}$ & $P$ value $^{\mathrm{a}}$ \\
\hline Age (years) & $35.8 \pm 8.8$ & $40.7 \pm 13.8$ & $31.0 \pm 9.8$ & $35.7 \pm 8.8$ & $33.0 \pm 11.0$ & 0.11 \\
\hline Female sex (no.) & 16 & 16 & 5 & $8^{-}$ & 13 & 0.13 \\
\hline Heart rate $(\mathrm{bpm})$ & $67 \pm 9$ & $66 \pm 11$ & $62 \pm 8$ & $70 \pm 13$ & $65 \pm 11$ & 0.74 \\
\hline Systolic BP (mmHg) & $118 \pm 11$ & $117 \pm 12$ & $121 \pm 9$ & $115 \pm 8$ & $117 \pm 12$ & 0.80 \\
\hline Diastolic BP (mmHg) & $77 \pm 10$ & $78 \pm 10$ & $81 \pm 9$ & $75 \pm 7$ & $78 \pm 9$ & 0.67 \\
\hline Serum $\mathrm{FT}_{4}(\mathrm{ng} / \mathrm{dl})^{\mathrm{b}}$ & $1.02 \pm 0.15$ & $0.29 \pm 0.13^{\mathrm{c}}$ & $0.45 \pm 0.14^{\mathrm{C}}$ & $0.94 \pm 0.24$ & $0.95 \pm 0.14$ & $<0.001$ \\
\hline Serum TSH (mU/l) & $1.70 \pm 1.03$ & $97.17 \pm 53.75^{\mathrm{c}}$ & $3.26 \pm 3.35$ & $14.28 \pm 5.59^{c}$ & $0.99 \pm 1.08$ & $<0.001$ \\
\hline
\end{tabular}

$\mathrm{BP}$, blood pressure; $\mathrm{FT}_{4}$, free thyroxine; $\mathrm{TSH}$, thyrotropin.

${ }^{a} P$ values are for the comparisons between all groups by ANOVA, except for sex distribution $\left(\chi^{2}\right.$ test).

${ }^{\mathrm{b}}$ To convert serum $\mathrm{FT}_{4}$ from nanograms per deciliter to picomole per liter multiply by 12.87 .

${ }^{\mathrm{c}} P$ value $<0.05$ for comparisons between patients and controls (Dunnett's or Dunn's multiple comparison test).

reliable evaluation of cardiac structure and function (12). Previous echocardiographic studies have demonstrated alterations in systolic and diastolic parameters in both overt and subclinical primary hypothyroidism $(13,14,15,16,17)$. In this study, we tested the hypothesis that selected parameters of myocardial function by echocardiography could be useful in diagnosing subclinical central hypothyroidism in patients with hypothalamic-pituitary disease and normal serum $\mathrm{FT}_{4}$ levels.

\section{Materials and methods}

\section{Patients and controls}

The study included 35 patients with hypothalamic-pituitary disease (ten macroprolactinomas, six craniopharyngiomas, six idiopathic hypopituitarism, five Sheehan's syndrome, five nonfunctioning pituitary macroadenomas, one sarcoidosis, one Langerhans cell histiocytosis, and one brain traumatic injury), irrespective of previous surgery, radiotherapy, pharmacological treatment, or hormone replacement therapy (including $\mathrm{T}_{4}$ ), and 30 patients with primary hypothyroidism, diagnosed by high serum TSH, due to Hashimoto's thyroiditis $(n=28)$ or previous thyroidectomy. Patients were carefully evaluated to exclude hypertension or coexisting primary cardiac disease which could interfere with the echocardiographic results; patients with acromegaly or Cushing's disease were not included due to the frequent association with hypertension and/or cardiac hypertrophy.

Patients with hypothalamic-pituitary disease and low serum $\mathrm{FT}_{4}$ were classified as overt central hypothyroidism; patients with primary thyroid disease, high serum TSH, and low serum $\mathrm{FT}_{4}$ as overt primary hypothyroidism; and patients with primary thyroid disease, high $\mathrm{TSH}$, and normal serum $\mathrm{FT}_{4}$ as subclinical primary hypothyroidism. Patients with hypothalamic-pituitary disease and normal serum $\mathrm{FT}_{4}$ were further classified as subclinical central hypothyroidism or euthyroidism according to echocardiography.

Twenty-eight healthy subjects were included as controls. Patients and controls were studied after informed consent and study approval by the Ethic Committee.

\section{Study design}

Baseline assessment Patients were submitted to physical exam and baseline hormonal and echocardiographic assessment. Fasting morning blood collection for hormone measurements and echocardiographic evaluation were performed on the same day.

Table 2 Baseline echocardiographic parameters in patients with overt primary hypothyroidism, overt central hypothyroidism, and controls. Plus-minus values are means \pm s.D.

\begin{tabular}{|c|c|c|c|c|}
\hline & Controls $(n=28)$ & $\begin{array}{c}\text { Overt primary } \\
\text { hypothyroidism }(n=20)\end{array}$ & $\begin{array}{c}\text { Overt central } \\
\text { hypothyroidism }(n=10)\end{array}$ & $P$ value $^{\mathrm{a}}$ \\
\hline Left ventricle ejection fraction & $0.67 \pm 0.04$ & $0.63 \pm 0.05^{b}$ & $0.61 \pm 0.05^{b}$ & 0.003 \\
\hline MPI & $0.40 \pm 0.05$ & $0.65 \pm 0.15^{b}$ & $0.51 \pm 0.10^{\mathrm{b}}$ & $<0.001$ \\
\hline ICT (ms) & $39 \pm 10$ & $74 \pm 23^{b}$ & $75 \pm 24^{\mathrm{b}}$ & $<0.001$ \\
\hline ICT/ET ratio & $0.13 \pm 0.03$ & $0.28 \pm 0.11^{b}$ & $0.25 \pm 0.08^{\mathrm{b}}$ & $<0.001$ \\
\hline $\mathrm{ET}(\mathrm{ms})$ & $298 \pm 16$ & $271 \pm 24^{\mathrm{b}}$ & $298 \pm 25$ & $<0.001$ \\
\hline Isovolumic relaxation time (ms) & $80 \pm 13$ & $99 \pm 23^{b}$ & $77 \pm 16$ & $<0.001$ \\
\hline
\end{tabular}

ICT, isovolumic contraction time; ICT/ET, ICT/ejection time; MPI, myocardial performance index.

${ }^{a} P$ values are for the comparisons between all groups by ANOVA.

${ }^{\mathrm{b}} \mathrm{P}$ value $<0.05$ for comparisons between patients and controls (Dunnett's multiple comparison test). 
$\boldsymbol{T}_{4}$ intervention Patients with overt primary hypothyroidism, overt central hypothyroidism, subclinical primary hypothyroidism, and hypothalamic-pituitary disease with normal serum $\mathrm{FT}_{4}$ and echocardiographically defined hypothyroidism (subclinical central hypothyroidism) were started on levothyroxine (L- $\mathrm{T}_{4}$; $1.0-1.7 \mu \mathrm{g} / \mathrm{kg}$ of body weight per day) and/or increased by $25 \mu \mathrm{g}$ every $4-6$ weeks until reaching the following: normal serum TSH in overt and subclinical primary hypothyroidism; normal serum $\mathrm{FT}_{4}$ in overt central hypothyroidism (mid-range/high-normal); and a higher than baseline serum $\mathrm{FT}_{4}$ (mid-range/high-normal) in subclinical central hypothyroidism. Patients were monitored for signs and symptoms of thyrotoxicosis; patients with hypothalamic-pituitary disease were also monitored through serum triiodothyronine $\left(\mathrm{T}_{3}\right)$ measurements. Echocardiography was repeated when hormonal targets were reached. Replacement of other hormone deficiencies was kept constant for at least 6 months before and during the study.

\section{Hormone assays}

Serum TSH was measured in duplicate by an in-house sensitive third-generation immunofluorometric assay (intra- and interassay coefficients of variation (CV), 4 and $6 \%$ respectively; sensitivity, $0.03 \mathrm{mU} / \mathrm{l}$; and normal reference values: $0.4-5.0 \mathrm{mU} / \mathrm{l}$ ). Serum $\mathrm{FT}_{4}$ was measured in duplicate by an immunofluorometric assay (Delfia; Wallac Oy, Turku, Finland; intra- and interassay CV, 4.4 and $6.1 \%$ respectively; sensitivity, $0.16 \mathrm{ng} / \mathrm{dl}$; and normal reference values: $0.7-1.54 \mathrm{ng} / \mathrm{dl}$ ). Serum $\mathrm{T}_{3}$ (total) was measured by an immunofluorometric assay (Delfia; Wallac Oy; intraand interassay $\mathrm{CV}, 3.0 \%$; sensitivity, $20 \mathrm{ng} / \mathrm{dl}$; and normal reference values, $80-210 \mathrm{ng} / \mathrm{dl}$ ).

\section{Echocardiographic assessment}

A complete two-dimensional Doppler echocardiographic examination was performed using an ATL5000 ultrasound machine (Philips, Andover, MA, USA) with a 2.0-2.5 MHz transducer according to standard technique (12). Left ventricle ejection fraction was obtained by Teichholz method (18). Assessment of the myocardial performance index (MPI) (19), defined as the sum of isovolumic contraction time (ICT) and isovolumic relaxation time divided by left ventricle ejection time (ET), was carried out by sequential recording of the mitral inflow (from the apical fourchamber view with the pulsed wave Doppler sample volume positioned at the tips of the mitral leaflets during diastole) and of the left ventricle outflow tract (from the apical long axis view with the sample volume positioned just below the aortic valve). Measurements of Doppler tracings were performed with simultaneous electrocardiogram recording in five consecutive heart beats and expressed as the mean value as previously described
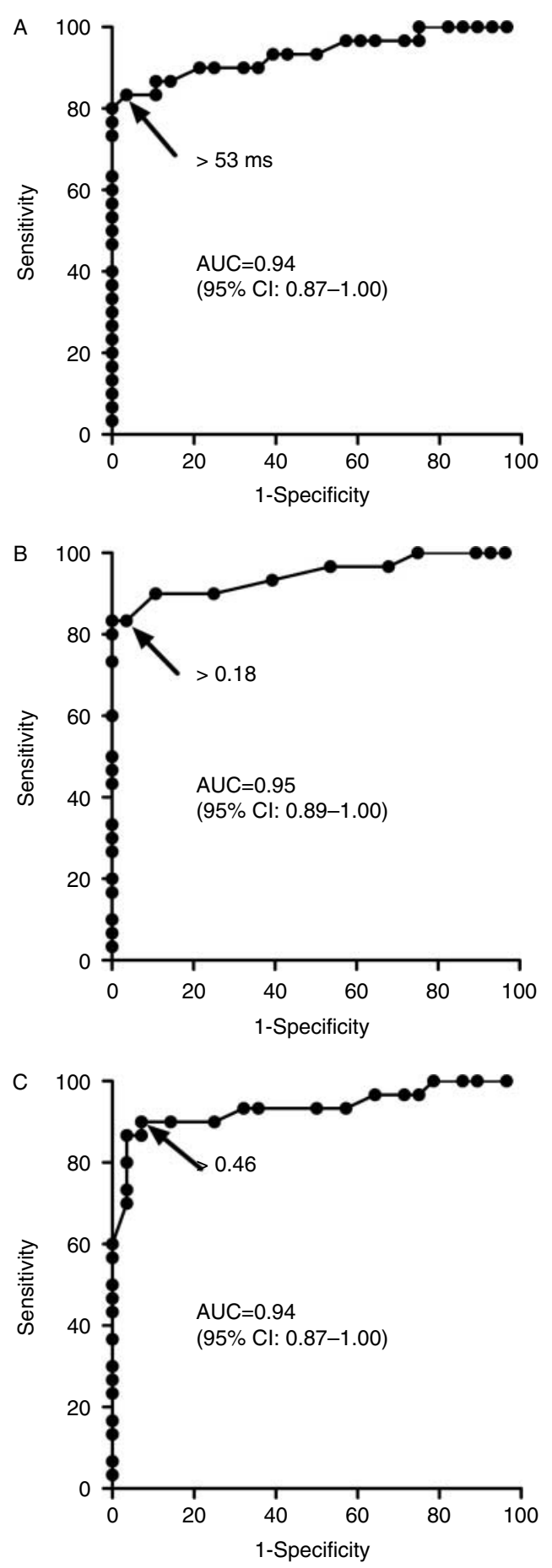

Figure $1 \mathrm{ROC}$ curves and the corresponding AUC for (A) the isovolumic contraction time (ICT), (B) the ratio between ICT and ejection time, and (C) the myocardial performance index (MPI) as markers of hypothyroidism in patients with overt primary and central hypothyroidism. An AUC value of 0.5 is no better than expected by chance and a value of 1.0 indicates a perfect diagnostic marker. Arrows indicate the chosen diagnostic cut-off values. 
(20). Measurements were made by a single observer (FCD) uninformed of patients' data.

\section{Statistical analysis}

Comparisons between more than two groups were made by ANOVA, followed by paired or unpaired parametric or nonparametric post hoc tests. Correlations were calculated using Pearson's $(r)$ or Spearman's $\left(r_{\mathrm{S}}\right)$ coefficients. Comparison between frequencies were calculated by $\chi^{2}$ or Fisher's exact test. Receiver operating characteristic (ROC) curves were generated using selected echocardiographic parameters from controls and patients with biochemical overt hypothyroidism according to currently accepted diagnostic gold standards: low serum $\mathrm{FT}_{4}$ with low, normal, or slightly increased TSH in patients with hypothalamic-pituitary disease for central hypothyroidism; and low serum $\mathrm{FT}_{4}$ with high TSH in patients with primary thyroid disease. Echocardiographic parameters from patients with subclinical primary hypothyroidism or hypothalamic-pituitary disease with normal serum $\mathrm{FT}_{4}$ were not used to generate the ROC curves and served as application groups. $P$ values $<0.05$ were considered significant. Statistical analyses were performed using GraphPad Prism version 5.00 for Windows (GraphPad Software Inc., San Diego, CA, USA, www.graphpad.com). Data were expressed as mean \pm s.D.

\section{Results}

No significant differences were found in age, sex distribution, heart rate, or blood pressure between patients with overt primary hypothyroidism, overt central hypothyroidism, subclinical primary hypothyroidism, hypothalamic-pituitary disease with normal serum $\mathrm{FT}_{4}$, and controls (Table 1).

\section{Baseline assessment in overt hypothyroidism}

As expected, serum $\mathrm{FT}_{4}$ was significantly lower in both overt primary and overt central hypothyroidism as compared with controls, and serum TSH was significantly higher in overt primary hypothyroidism but not in overt central hypothyroidism as compared with controls (Table 1).

As shown in Table 2, left ventricle ejection fraction, MPI, ICT, and ICT/ET ratio were significantly different from controls in both overt primary and overt central hypothyroidism. Left ventricle ET and isovolumic relaxation time were significantly different only in overt primary hypothyroidism. No significant differences in ventricular dimensions and left ventricle mass index were observed (data not shown). One patient with primary hypothyroidism presented mild pericardial effusion.

\section{ROC curves analysis of echocardiographic parameters in the diagnosis of hypothyroidism}

Figure 1 shows the echocardiographic parameters with the highest areas under the ROC curves. The chosen cut-off values for the diagnosis of hypothyroidism were the following: ICT $>53 \mathrm{~ms}$ (sensitivity, 83\%; confidence interval (CI), 65-94\%; specificity, 96\%; CI, 82-100\%); ICT/ET ratio >0.18 (sensitivity, 83\%; CI, 65-94\%; specificity, 96\%; CI, $82-100 \%)$; and MPI $>0.46$ (sensitivity, 90\%; CI, 74-98\%; specificity, 93\%; CI, 77-99\%). For ICT and ICT/ET ratio, cut-off values showed identical accuracy, positive, and negative predictive values of 90,96 , and $84 \%$ respectively. For MPI, accuracy, positive, and negative predictive values were 91,93 , and 90\% respectively. A highest diagnostic accuracy of $93 \%$ was obtained when at least one parameter was increased (positive and negative predictive values, 93\%). Intra- and interobserver variability (percent of mean value) for MPI, ICT, and ICT/ET ratio were $2.7 \pm 2.2,5.9 \pm 5.9,4.1 \pm 2.9,6.3 \pm 7$, and $9.1 \pm 5.6,9.4 \pm 4 \%$ respectively.

\section{Echocardiographic diagnosis of hypothyroidism in patients with normal serum FT 4}

Serum $\mathrm{FT}_{4}$ levels in patients with subclinical primary hypothyroidism and in patients with hypothalamicpituitary disease with normal $\mathrm{FT}_{4}$ were not significantly different from controls. As expected, serum TSH levels

Table 3 Baseline echocardiographic parameters in patients with subclinical primary hypothyroidism, hypothalamic-pituitary disease with normal serum $\mathrm{FT}_{4}$ and controls. Plus-minus values are means \pm s.D.

\begin{tabular}{|c|c|c|c|c|}
\hline & Controls $(n=28)$ & $\begin{array}{c}\text { Subclinical primary } \\
\text { hypothyroidism }(n=10)\end{array}$ & $\begin{array}{l}\text { Hypothalamic-pituitary } \\
\text { normal } \mathrm{FT}_{\mathbf{4}}(n=25)\end{array}$ & $P$ value $^{\mathrm{a}}$ \\
\hline Left ventricle ejection fraction & $0.67 \pm 0.04$ & $0.67 \pm 0.04$ & $0.62 \pm 0.03^{b}$ & $<0.001$ \\
\hline MPI & $0.40 \pm 0.05$ & $0.48 \pm 0.09^{b}$ & $0.43 \pm 0.07$ & 0.005 \\
\hline ICT (ms) & $39 \pm 10$ & $53 \pm 11^{\mathrm{b}}$ & $55 \pm 17^{\mathrm{b}}$ & $<0.001$ \\
\hline ICT/ET ratio & $0.13 \pm 0.03$ & $0.19 \pm 0.04^{b}$ & $0.18 \pm 0.06^{b}$ & $<0.001$ \\
\hline $\mathrm{ET}(\mathrm{ms})$ & $298 \pm 16$ & $288 \pm 27$ & $302 \pm 16$ & 0.12 \\
\hline Isovolumic relaxation time (ms) & $80 \pm 13$ & $84 \pm 16$ & $78 \pm 16$ & 0.50 \\
\hline
\end{tabular}

FT4, free thyroxine; ICT, isovolumic contraction time; ICT/ET, ICT/ejection time; MPI, myocardial performance index.

${ }^{a} P$ values are for the comparisons between all groups by ANOVA.

${ }^{\mathrm{b}} P$ value $<0.05$ for comparisons between patients and controls (Dunnett's multiple comparison test). 
were significantly higher in subclinical primary hypothyroidism, but not in hypothalamic-pituitary disease with normal $\mathrm{FT}_{4}$, as compared with controls (Table 1). No significant differences in ventricular dimensions and left ventricle mass indexes were observed among these groups (data not shown).

\section{Subclinical primary hypothyroidism}

As shown in Table 3, all three diagnostic echocardiographic parameters were significantly increased in subclinical primary hypothyroidism. Eight of ten patients with subclinical primary hypothyroidism were also diagnosed as hypothyroid by echocardiography (Fig. 2).

\section{Hypothalamic-pituitary disease with normal $\operatorname{serum} \mathrm{FT}_{4}$}

As shown in Table 3, both ICT and ICT/ET ratio were significantly increased, and left ventricle ejection fraction was significantly decreased in hypothalamicpituitary disease with normal serum $\mathrm{FT}_{4}$.

Hypothyroidism was diagnosed by echocardiography in 14 of 25 patients (56\%) with hypothalamic-pituitary disease and normal serum $\mathrm{FT}_{4}$ (Fig. 2). These patients were younger than patients echocardiographically defined as euthyroid $(28 \pm 8$ vs $40 \pm 11$ years, $P=0.004$, $t$-test), but no significant differences were found in sex, heart rate, blood pressure, serum $\mathrm{FT}_{4}$ and
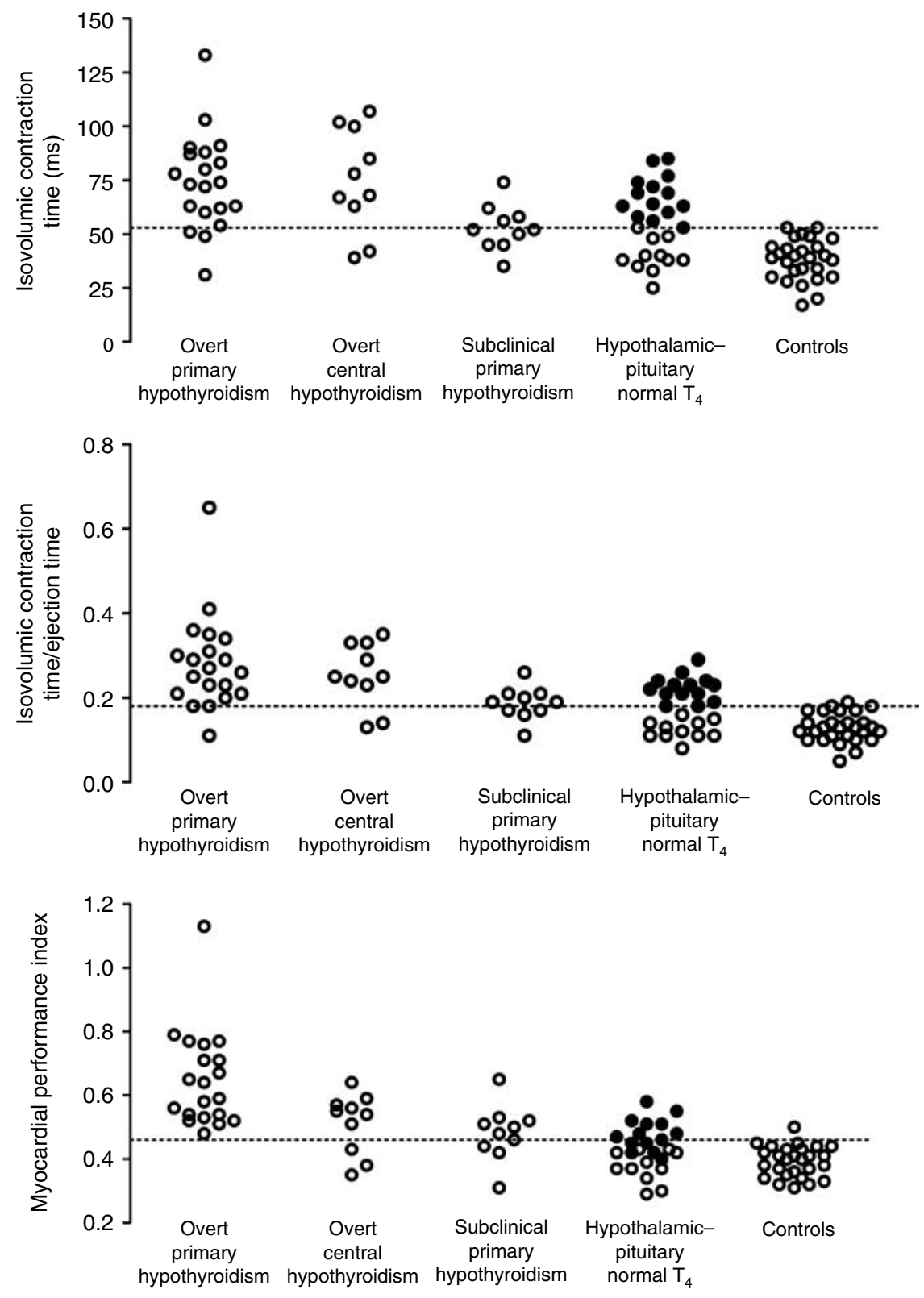

Figure 2 Selected diagnostic echocardiographic parameters in patients with overt and subclinical primary hypothyroidism, overt central hypothyroidism, hypothalamic-pituitary disease with normal serum free thyroxine $\left(\mathrm{FT}_{4}\right)$, and controls. Each circle represents one patient. Dashed horizontal lines indicate the chosen cut-off values: $53 \mathrm{~ms}$ for the ICT, 0.18 for the ratio between ICT and ET, and 0.46 for the MPI. Patients with hypothalamic-pituitary disease and normal $\mathrm{FT}_{4}$ that had at least one of the three parameters above the cut-off value were diagnosed as subclinical central hypothyroidism and are represented by solid circles. 
Table 4 Clinical and hormonal parameters in patients with or without echocardiographically defined subclinical central hypothyroidism. Plus-minus values are means \pm s.D.

\begin{tabular}{|c|c|c|c|}
\hline & \multicolumn{3}{|c|}{ Subclinical central hypothyroidism } \\
\hline & Yes $(n=14)$ & No $(n=11)$ & $P$ value ${ }^{a}$ \\
\hline Age (years) & $28 \pm 8$ & $40 \pm 11$ & 0.004 \\
\hline Female sex (no.) & 6 & 7 & 0.43 \\
\hline Heart rate (bpm) & $65 \pm 9$ & $64 \pm 9$ & 0.79 \\
\hline $\begin{array}{l}\text { Systolic blood } \\
\text { pressure }(\mathrm{mmHg})\end{array}$ & $118 \pm 14$ & $117 \pm 11$ & 0.85 \\
\hline $\begin{array}{l}\text { Diastolic blood } \\
\text { pressure }(\mathrm{mmHg})\end{array}$ & $79 \pm 8$ & $76 \pm 10$ & 0.41 \\
\hline Serum $\mathrm{FT}_{4}(\mathrm{ng} / \mathrm{dl})^{\mathrm{b}^{\prime}}$ & $0.96 \pm 0.14$ & $0.95 \pm 0.15$ & 0.87 \\
\hline Serum $\mathrm{T}_{3}(\mathrm{ng} / \mathrm{dl})^{\mathrm{c}}$ & $114 \pm 25$ & $105 \pm 9$ & 0.27 \\
\hline $\begin{array}{l}\text { Untreated GH } \\
\quad \text { deficiency (no.) }\end{array}$ & 9 & 9 & 0.41 \\
\hline Hypogonadism (no.) & 5 & 7 & 1 \\
\hline $\begin{array}{l}\text { Glucocorticoid } \\
\text { deficiency (no.) }\end{array}$ & 3 & 6 & 1 \\
\hline
\end{tabular}

$\mathrm{FT}_{4}$, free thyroxine; $\mathrm{T}_{3}$, triiodothyronine.

${ }^{\mathrm{a}} P$ values for comparisons between groups by unpaired $t$-test (age, heart rate, blood pressure, serum $\mathrm{FT}_{4}$, and $\mathrm{T}_{3}$ ) or Fisher's exact test (sex, untreated GH deficiency, hypogonadism, and glucocorticoid deficiency).

${ }^{\mathrm{b}} \mathrm{To}$ convert serum $\mathrm{FT}_{4}$ from nanograms per deciliter to picomole per liter multiply by 12.87 .

${ }^{c}$ To convert serum $T_{3}$ from nanograms per deciliter to nanomole per liter multiply by 0.0154 .

$\mathrm{T}_{3}$, prevalence of untreated $\mathrm{GH}$ deficiency, or other pituitary hormone deficiencies (Table 4).

\section{Baseline echocardiographic and hormonal correlations}

In primary hypothyroidism, as expected, the highest correlation was found between serum TSH and serum $\mathrm{FT}_{4}\left(r_{\mathrm{S}}=-0.70, \quad P<0.001\right)$; serum TSH was also correlated with ICT $\left(r_{\mathrm{S}}=0.53, P=0.003\right)$, ICT/ET ratio $\left(r_{\mathrm{S}}=0.54, P=0.002\right)$, and MPI $\left(r_{\mathrm{S}}=0.55\right.$, $P=0.002) . \mathrm{FT}_{4}$ correlated with ICT $\left(r_{\mathrm{S}}=-0.54\right.$, $P=0.002)$, ICT/ET ratio $\left(r_{\mathrm{S}}=-0.55, P=0.002\right)$, and MPI $\left(r_{\mathrm{S}}=-0.62, P<0.001\right)$.

In central hypothyroidism, diagnosed either biochemically or echocardiographically, the highest correlation was between serum $\mathrm{FT}_{4}$ and the MPI $(r=-0.79, \quad P<0.001)$; serum $\mathrm{FT}_{4}$ also correlated with ICT $(r=-0.52, P=0.02)$ and ICT/ET ratio $(r=-0.60, P=0.006)$.

\section{Changes after $T_{4}$ intervention}

Fifty-four patients met the criteria for $\mathrm{T}_{4}$ intervention; 43 completed the study (Fig. 3 and Table 5). Two thyroidectomized patients were not included because TSH levels were suppressed after $\mathrm{L}-\mathrm{T}_{4}$ and four patients were not available on recall. Five patients were excluded due to poor compliance. No patient developed clinical signs and/or symptoms of excessive $\mathrm{T}_{4}$ replacement.
$\mathrm{L}-\mathrm{T}_{4}$ significantly increased serum $\mathrm{FT}_{4}$ in all groups, but did not significantly change heart rate and blood pressure. Mean serum TSH decreased to the normal range in primary hypothyroidism and serum $\mathrm{T}_{3}$ increased within the normal range in all patients with hypothalamic-pituitary disease.

\section{Overt hypothyroidism}

After treatment, all diagnostic echocardiographic parameters decreased significantly in overt hypothyroidism. In overt primary hypothyroidism, these three
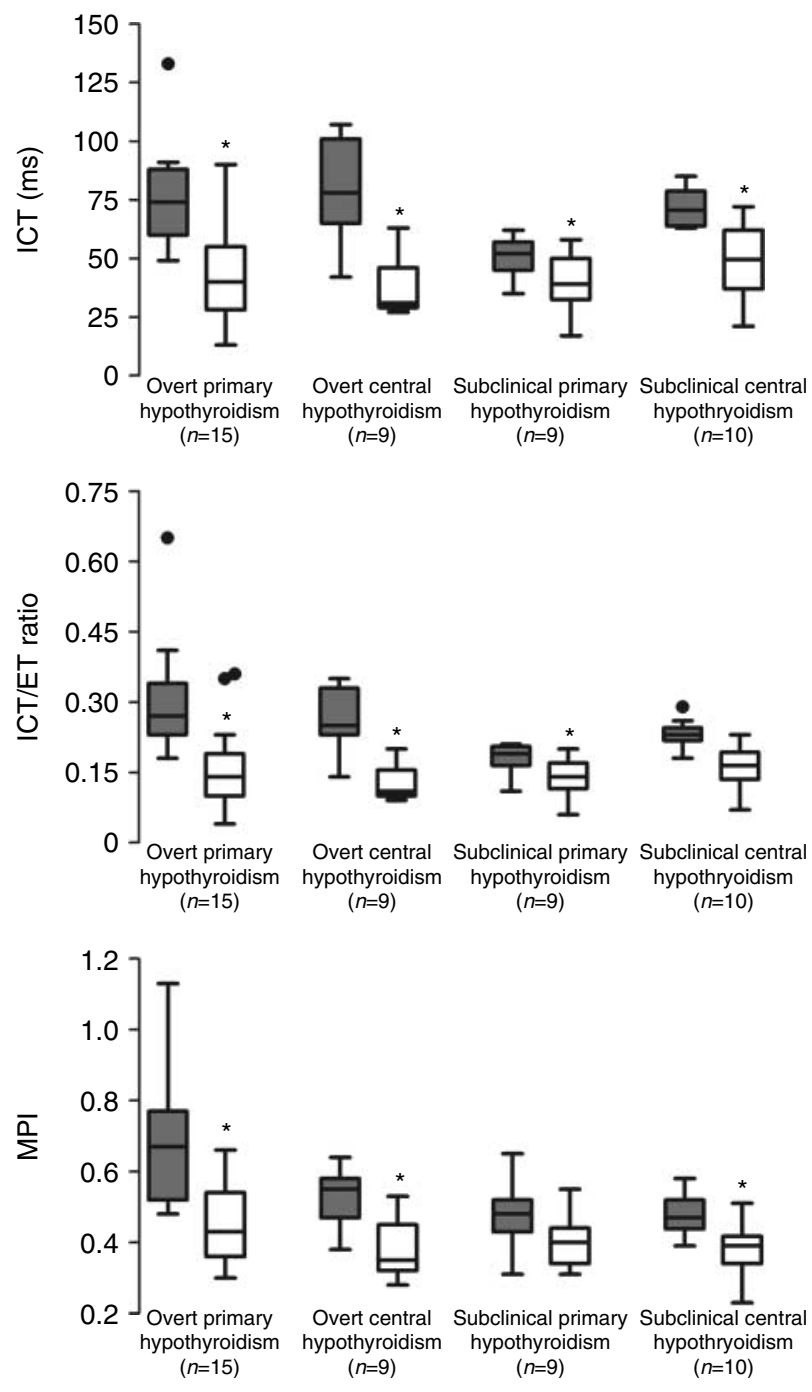

Figure 3 Diagnostic parameters before and after thyroxine $\left(T_{4}\right)$ intervention in patients with overt primary, overt central, subclinical primary, and subclinical central hypothyroidism. Box and whisker plots show the 10th, 25th, 50th (median), 75th, and 90th percentile values for the isovolumic contraction time (ICT), the ratio between ICT and ejection time (ET), and the myocardial performance index, before (gray boxes) and after (white boxes) $\mathrm{T}_{4}$ intervention in patients with primary and central overt and subclinical hypothyroidism. ${ }^{*} P<0.05$, paired $t$-test. Black dots represent outliers. Values in parentheses are the numbers of patients in each group. 
Table 5 Clinical, hormonal, and echocardiographic parameters before and after $T_{4}$ intervention in patients with overt primary hypothyroidism, overt central hypothyroidism, subclinical primary hypothyroidism, and echocardiographically defined subclinical central hypothyroidism. Plus-minus values are means \pm s.D.

\begin{tabular}{|c|c|c|c|c|c|c|c|c|}
\hline \multirow[b]{2}{*}{$T_{4}$ intervention } & \multicolumn{2}{|c|}{$\begin{array}{c}\text { Overt primary } \\
\text { hypothyroidism }(n=15)\end{array}$} & \multicolumn{2}{|c|}{$\begin{array}{c}\text { Overt central } \\
\text { hypothyroidism }(n=9)\end{array}$} & \multicolumn{2}{|c|}{$\begin{array}{c}\text { Subclinical primary } \\
\text { hypothyroidism }(n=9)\end{array}$} & \multicolumn{2}{|c|}{$\begin{array}{c}\text { Subclinical central } \\
\text { hypothyroidism }(n=10)\end{array}$} \\
\hline & Before & After & Before & After & Before & After & Before & After \\
\hline Hear & $67 \pm 11$ & $69 \pm 11$ & $62 \pm 8$ & $68 \pm 9$ & $67 \pm 14$ & $72 \pm 11$ & $65 \pm 11$ & $72 \pm 9.6$ \\
\hline Systolic BP $(\mathrm{mmHg})$ & $117 \pm 11$ & $117 \pm 12$ & $122 \pm 10$ & $118 \pm 19$ & $117 \pm 7$ & $114 \pm 11$ & $121 \pm 15$ & $128 \pm 10$ \\
\hline $\mathrm{BP}(\mathrm{mmHg})$ & $77 \pm 10$ & $77 \pm 7$ & $82 \pm 9$ & $78 \pm 13$ & $77 \pm 5$ & $77 \pm 6$ & & $88 \pm 4$ \\
\hline Serum $\mathrm{FT}_{4}(\mathrm{ng} / \mathrm{dl})^{\mathrm{a}}$ & $0.29 \pm 0.12$ & $1.14 \pm 0.18^{\mathrm{b}}$ & $0.45 \pm 0.15$ & $1.22 \pm 0.43^{\mathrm{b}}$ & $0.96 \pm 0.24$ & $1.14 \pm 0.18^{b}$ & $0.96 \pm 0.15$ & $1.38 \pm 0.22^{b}$ \\
\hline Serum $T_{3}(n g / d l)^{c}$ & NA & $\overline{N A}$ & $82 \pm 26$ & $127 \pm 29^{b}$ & NA & $\bar{N} A$ & $103 \pm 21$ & $140 \pm 31^{b}$ \\
\hline Serum TSH (mU/l) & $00.30 \pm 59.10$ & $2.43 \pm 1.34^{\mathrm{b}}$ & $3.61 \pm 3.34$ & $\overline{N A}$ & $13.0 \pm 4.13$ & $2.28 \pm 1.54^{b}$ & $0.89 \pm 1.17$ & $\overline{N A}$ \\
\hline $\begin{array}{l}\text { Left ventricle ejection } \\
\text { fraction }\end{array}$ & $0.62 \pm 0.05$ & $0.66 \pm 0.04^{b}$ & $0.61 \pm 0.05$ & $0.63 \pm 0.04$ & $0.67 \pm 0.04$ & $0.67 \pm 0.05$ & $0.64 \pm 0.03$ & $0.64 \pm 0.05$ \\
\hline MPI & $0.67 \pm 0.05$ & $0.44 \pm 0.10^{b}$ & $0.53 \pm 0.08$ & $0.38 \pm 0.08^{b}$ & $0.48 \pm$ & $0.40 \pm$ & $0.48 \pm 0.06$ & $0.39 \pm 0.09^{b}$ \\
\hline ICT (ms) & $76 \pm 21$ & $45 \pm 23^{b}$ & $79 \pm 21$ & $38 \pm 13^{\mathrm{b}}$ & $51 \pm 8$ & $40 \pm 13^{b}$ & $72 \pm 8$ & $52 \pm 19^{b}$ \\
\hline ICT/ET ratio & $0.30 \pm 0.12$ & $0.16 \pm 0.10^{\mathrm{b}}$ & $0.27 \pm 0.07$ & $0.13 \pm 0.04^{\mathrm{b}}$ & $0.18 \pm 0.03$ & $0.14 \pm 0.04^{b}$ & $0.23 \pm 0.03$ & $0.17 \pm 0.06^{\mathrm{b}}$ \\
\hline $\mathrm{ET}(\mathrm{ms})$ & $266 \pm 24$ & $285 \pm 26^{b}$ & $296 \pm 26$ & $293 \pm 20$ & $288 \pm 28$ & $287 \pm 18$ & $305 \pm 0$ & $302 \pm 17$ \\
\hline $\begin{array}{l}\text { Isovolumic relaxation } \\
\text { time (ms) }\end{array}$ & $99 \pm 23$ & $81 \pm 20^{b}$ & $78 \pm 16$ & $73 \pm 16$ & $85 \pm 16$ & $75 \pm 17^{b}$ & $73 \pm 15$ & $67 \pm 18$ \\
\hline
\end{tabular}

$\mathrm{BP}$, blood pressure; $\mathrm{FT}_{4}$, free thyroxine; $\mathrm{T}_{3}$, triiodothyronine; $\mathrm{TSH}$, thyrotropin; $\mathrm{NA}$, not applicable; ICT, isovolumic contraction time; ICT/ET, ICT/ejection time; MPI, myocardial performance index.

${ }^{\text {a }}$ To convert serum $\mathrm{FT}_{4}$ from nanograms per deciliter to picomole per liter multiply by 12.87 .

${ }^{\mathrm{b}} P$ value $<0.05$ for comparisons between parameters before and after thyroxine intervention (paired $t$-test).

${ }^{\mathrm{c}}$ To convert serum $\mathrm{T}_{3}$ from nanograms per deciliter to nanomole per liter multiply by 0.0154 .

parameters decreased in all 15 patients and each one reached values lower than the mean +2 s.D. of control subjects in $73-77 \%$ of patients. In overt central hypothyroidism, these parameters also decreased in all nine patients, and all but one of each diagnostic parameter decreased below mean +2 s.D. of controls. After $\mathrm{T}_{4}$, echocardiographic measurements below the mean -2 s.D. were observed in four of 24 patients.

\section{Subclinical hypothyroidism}

$\mathrm{T}_{4}$ intervention significantly decreased all diagnostic echocardiographic parameters in both subclinical primary and subclinical central hypothyroidism, and corrected 28 of $29(97 \%)$ abnormal parameters in subclinical primary hypothyroidism, and 21 of 29 $(72 \%)$ in subclinical central hypothyroidism. Low echocardiographic measurements (<mean -2 s.D.) were observed in two of 18 patients.

\section{Echocardiographic and hormonal correlations after $T_{4}$}

Significant correlations were found between changes ( $\Delta=$ posttreatment minus pretreatment values) in serum thyroid hormones and changes in diagnostic echocardiographic parameters in patients with primary and central hypothyroidism (overt and subclinical).

In primary hypothyroidism, $\triangle \mathrm{TSH}$ correlated $(0.01<\mathrm{P}<0.001)$ with $\Delta \mathrm{FT}_{4}\left(r_{\mathrm{S}}=-0.67\right), \Delta \mathrm{ICT}$ $\left(r_{\mathrm{S}}=0.63\right), \Delta \mathrm{ICT} / \mathrm{ET}$ ratio $\left(r_{\mathrm{S}}=0.68\right)$, and $\Delta \mathrm{MPI}$ $\left(r_{\mathrm{S}}=0.66\right) ; \quad \Delta \mathrm{FT}_{4}$ correlated $(0.01<P<0.001)$ with $\Delta \mathrm{ICT}(r=-0.60), \Delta \mathrm{ICT} / \mathrm{ET}$ ratio $\left(r_{\mathrm{S}}=-0.55\right)$, and $\Delta \mathrm{MPI}\left(r_{\mathrm{S}}=-0.62\right)$.
In central hypothyroidism, $\Delta \mathrm{FT}_{4}$ correlated $(0.05<P<0.01)$ with $\Delta \mathrm{ICT}(r=-0.51), \quad \Delta \mathrm{ICT} / \mathrm{ET}$ ratio $(r=-0.50)$, and $\Delta \mathrm{MPI}\left(r_{\mathrm{S}}=-0.72\right)$.

As shown in Fig. 4, when all patients with both primary and central overt and subclinical hypothyroidism were analyzed together, $\Delta \mathrm{FT}_{4}$ correlated significantly with $\triangle \mathrm{ICT}(r=-0.54), \Delta \mathrm{ICT} / \mathrm{ET}$ ratio $(r=-0.64)$, and $\triangle \mathrm{MPI}\left(r_{\mathrm{S}}=-0.70\right)$.

\section{Discussion}

In this study, we have shown that echocardiography is a simple and accurate method to detect tissue hypothyroidism, which was especially useful in diagnosing subclinical central hypothyroidism in patients with hypothalamicpituitary disease and normal serum $\mathrm{FT}_{4}$. As opposed to subclinical primary hypothyroidism, which is easily diagnosed by increased serum TSH with normal serum $\mathrm{FT}_{4}$ levels, the diagnosis of subclinical central hypothyroidism has been elusive in clinical practice. Selected myocardial function parameters including the systolic time intervals - ICT and ICT/ET ratio - and the MPI, which are largely independent of heart rate $(11,21)$, have shown high diagnostic accuracy as demonstrated by ROC curve analysis using only patients with overt central and primary hypothyroidism and controls. When applied to patients with subclinical primary hypothyroidism, these markers were in diagnostic agreement with serum TSH levels in $80 \%$ of cases. In patients with hypothalamicpituitary disease and normal serum $\mathrm{FT}_{4}$ who were considered at risk for subclinical central hypothyroidism, these markers indicated tissue hypothyroidism in 56\% of patients. The specificity of these measurements to detect 

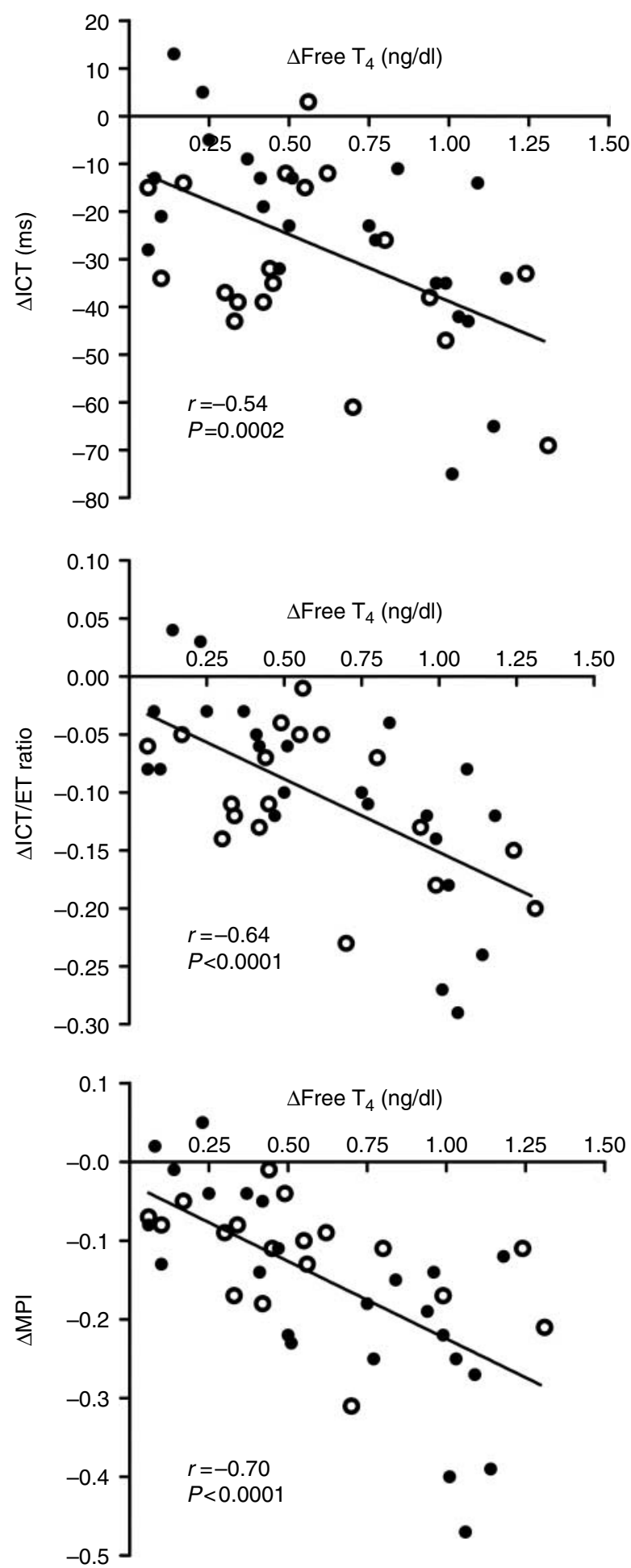

Figure 4 Correlations between changes ( $\Delta=$ posttreatment minus pretreatment values) in serum $\mathrm{FT}_{4}$ and each echocardiographic diagnostic parameter after levothyroxine in patients with primary (solid circles) and central (open circles) overt and subclinical hypothyroidism $(n=42)$. Slanting lines represent linear regression lines between parameters. $\mathrm{FT}_{4}$, free thyroxine; ICT, isovolumic contraction time; ICT/ET, ICT/ejection time ratio; MPI, myocardial performance index. tissue thyroid hormone deficiency was further supported by their reversal or improvement after $\mathrm{T}_{4}$, without any clinical or biochemical sign of excessive $\mathrm{T}_{4}$ replacement, in both biochemical and echocardiographically defined hypothyroidism.

The pathophysiology of disturbed myocardial performance in hypothyroidism, as reflected by alterations in several echocardiographic parameters, involves both direct and indirect effects of thyroid hormone in the heart. At the molecular level, these disturbances have been shown to result from both genomic and nongenomic effects of thyroid hormone in the cardiovascular system (6). Thyroid hormone regulates the expression of structural proteins, like $\alpha$ - and $\beta$-myosin heavy chains in cardiac myocytes, and of key regulatory proteins through binding of $\mathrm{T}_{3}$ to nuclear receptors that activate or repress transcription of several specific genes. Intracellular calcium cycling via sarcoplasmic reticulum calcium-activated ATPase and its inhibitor, phospholamban, which are regulated by thyroid hormone in opposite ways, is thought to be largely responsible for enhanced contractile function and diastolic relaxation (22). These mechanisms underlie the reduced velocity of shortening and rate of tension development observed in papillary muscle from hypothyroid animals (23). Hypothyroidism, at any end-diastolic volume, blunts the development of myocardial force in early systole, which lengthens the time required for the intraventricular pressure to reach the arterial diastolic pressure and initiate the ejective phase.

Impaired development of myocardial force plays a major role in the abnormalities found in ICT and ICT/ET ratio, both in primary and central hypothyroidism, which improved after $\mathrm{T}_{4}$ replacement in correlation with changes in serum thyroid hormone levels. In addition, left ventricle ejection fraction, a much less sensitive marker of tissue hypothyroidism, was significantly decreased in overt hypothyroidism and also improved after treatment. Although diastolic function, as reflected by the isovolumic relaxation time, was significantly impaired only in overt primary hypothyroidism, it was improved by $\mathrm{T}_{4}$ replacement in both overt and subclinical primary hypothyroidism. MPI, an index that combines both systolic (ICT and ET) and diastolic (isovolumic relaxation time) time intervals, was also increased in hypothyroidism and improved in correlation with changes in serum thyroid hormones.

Although other pituitary hormone deficiencies like $\mathrm{GH}$, glucocorticoid, and sex steroids were highly prevalent in our patients with hypothalamic-pituitary disease, they are unlikely to have had a major influence in the echocardiographic diagnosis of subclinical central hypothyroidism. First, these deficiencies, either treated or untreated, were equally distributed between patients with and without echocardiographically defined hypothyroidism. Second, similar abnormalities were also found in subclinical primary hypothyroidism with similar serum $\mathrm{FT}_{4}$ levels, which also improved after 
$\mathrm{T}_{4}$ replacement. Third, these echocardiographic abnormalities in patients with hypothalamic-pituitary disease and low serum $\mathrm{FT}_{4}$ were not more severe than in overt primary hypothyroidism.

A role for GH in heart morphology and function has been supported by clinical and experimental evidence (24, $25,26,27)$. Echocardiographic assessment of patients with GH deficiency has shown reduced cardiac mass, especially in childhood-onset deficiency, but the functional abnormalities have been reportedly subtle and best shown by radionuclide angiography (27). A meta-analysis of the echocardiographic effects of GH replacement in adults has shown improvement in left ventricle mass and stroke volume, but not in fractional shortening (28). However, none of these reports assessed the echocardiographic parameters selected in our study. Notwithstanding, the interaction between GH and thyroid hormones has relevant diagnostic and therapeutic implications in patients with hypothalamic-pituitary disease (29). Accordingly, GH replacement has been shown to decrease serum $\mathrm{FT}_{4}$ and reverse $\mathrm{T}_{3}$ and to increase serum $T_{3}$ by improving peripheral $T_{4}$ to $T_{3}$ conversion (30). In practice, the $\mathrm{T}_{4}$-lowering effect of $\mathrm{GH}$ has been shown to unmask biochemical hypothyroidism in $36-47 \%$ of patients with hypothalamic-pituitary disease $(31,32)$. On the other hand, since untreated $\mathrm{GH}$ deficiency is a state of decreased $\mathrm{T}_{3}$ generation and $\mathrm{GH}$ improves $\mathrm{T}_{4}$ biological effects, thyroid status can be influenced by GH replacement or withdrawal. In fact, we have shown that biologically appropriate target levels of serum $\mathrm{FT}_{4}$ during $\mathrm{L}-\mathrm{T}_{4}$ replacement should be higher in untreated GH deficiency (33).

The main limitation to the use of echocardiographic parameters in the diagnosis of hypothyroidism is the coexistence of cardiac disease. Accordingly, patients with positive clinical history of cardiac disease, hypertension, acromegaly, and Cushing's disease were not included and those with structural echocardiographic abnormalities were excluded by our study protocol. Nevertheless, further studies are necessary to elucidate whether these exclusion criteria could be less stringent in order to include hypertensive, acromegalic, and Cushing's disease patients with controlled hypertension who do not show any structural abnormalities in the echocardiographic evaluation. Another potential limitation is the use of drugs that could influence the diagnostic echocardiographic parameters via changes in circulating volume and/or peripheral vascular resistance, such as diuretics and some antihypertensive drugs, although their effects are reportedly small (34). Another potential, albeit limited influence is the age-related physiological impairment of myocardial relaxation that may increase MPI, but not ICT, especially after the sixth decade (35).

Patients with hypopituitarism have increased all-cause mortality with cardiovascular disease as the leading etiology (36). Analysis of mortality in hypopituitary cohorts has been challenging due to diversity of underlying etiologies, treatment modalities, hormone deficiencies, and hormone replacements (37). Subclinical primary hypothyroidism, on the other hand, has been associated with increased risk of coronary heart disease events and mortality (38). In this context, our results indicate that echocardiography should have a major role in assessing thyroid status in patients with hypothalamicpituitary disease and normal serum $\mathrm{FT}_{4}$ levels.

\section{Declaration of interest}

The authors declare that there is no conflict of interest that could be perceived as prejudicing the impartiality of the research reported.

\section{Funding}

The study was partially supported by the research grant of Centro de Estudos de Endocrinologia da Escola Paulista de Medicina (CENEPAM). The funding organization had no role in study design, data collection and analysis, decision to publish, or preparation of the manuscript.

\section{Acknowledgements}

The authors are grateful for the support from Erika Barbosa Ribeiro on the patients' selection work.

\section{References}

1 Beck-Peccoz P, Amr S, Menezes-Ferreira MM, Faglia G \& Weintraub BD. Decreased receptor binding of biologically inactive thyrotropin in central hypothyroidism. Effect of treatment with thyrotropin-releasing hormone. New England Journal of Medicine 1985312 1085-1090. (doi:10.1056/NEJM198504253121703)

2 Oliveira JH, Persani L, Beck-Peccoz P \& Abucham J. Investigating the paradox of hypothyroidism and increased serum thyrotropin (TSH) levels in Sheehan's syndrome: characterization of TSH carbohydrate content and bioactivity. Journal of Clinical Endocrinology and Metabolism 2001 86 1694-1699. (doi:10.1210/jc.86.4.1694)

3 Shimon I, Cohen O, Lubetsky A \& Olchovsky D. Thyrotropin suppression by thyroid hormone replacement is correlated with thyroxine level normalization in central hypothyroidism. Thyroid 200212 823-827. (doi:10.1089/105072502760339406)

4 Ferretti E, Persani L, Jaffrain-Rea ML, Giambona S, Tamburrano G \& Beck-Peccoz P. Evaluation of the adequacy of levothyroxine replacement therapy in patients with central hypothyroidism. Journal of Clinical Endocrinology and Metabolism 1999 84 924-929. (doi:10.1210/jc.84.3.924)

5 Hartoft-Nielsen ML, Lange M, Rasmussen AK, Scherer S, Zimmermann-Belsing $\mathrm{T} \&$ Feldt-Rasmussen U. Thyrotropinreleasing hormone stimulation test in patients with pituitary pathology. Hormone Research 200461 53-57. (doi:10.1159/ 000075239)

6 Klein I \& Ojamaa K. Thyroid hormone and the cardiovascular system. New England Journal of Medicine $20013 \mathbf{3 4 4} 501-509$. (doi:10.1056/NEJM200105103441901)

7 Amidi M, Leon DF, DeGroot WJ, Kroetz FW \& Leonard JJ. Effect of the thyroid state on myocardial contractility and ventricular ejection rate in man. Circulation 196838 229-239. (doi:10. 1161/01.CIR.38.2.229)

8 Taylor RR, Covell JW \& Ross J Jr. Influence of the thyroid state on left ventricular tension-velocity relations in the intact, sedated dog. Journal of Clinical Investigation $1969 \mathbf{4 8}$ 775-784. (doi:10.1172/ JCI106035)

9 Hillis WS, Bremner WF, Lawrie TD \& Thomson JA. Systolic time intervals in thyroid disease. Clinical Endocrinology $1975 \mathbf{4}$ 617-624. (doi:10.1111/j.1365-2265.1975.tb01931.x) 
10 Crowley WF Jr, Ridgway EC, Bough EW, Francis GS, Daniels GH, Kourides IA, Myers GS \& Maloof F. Noninvasive evaluation of cardiac function in hypothyroidism. Response to gradual thyroxine replacement. New England Journal of Medicine 1977296 1-6. (doi:10.1056/NEJM197701062960101)

11 Weissler AM, Harris WS \& Schoenfeld CD. Bedside technics for the evaluation of ventricular function in man. American Journal of Cardiology 196923 577-583. (doi:10.1016/0002-9149(69) 90012-5)

12 Lang RM, Bierig M, Devereux RB, Flachskampf FA, Foster E, Pellikka PA, Picard MH, Roman MJ, Seward J, Shanewise JS, Solomon SD, Spencer KT, Sutton MS \& Stewart WJ. Recommendations for chamber quantification: a report from the American Society of Echocardiography's Guidelines and Standards Committee and the Chamber Quantification Writing Group, developed in conjunction with the European Association of Echocardiography, a branch of the European Society of Cardiology. Journal of the American Society of Echocardiography 200518 1440-1463. (doi:10.1016/j.echo.2005.10.005)

13 Kahaly G, Mohr-Kahaly S, Beyer J \& Meyer J. Left ventricular function analyzed by Doppler and echocardiographic methods in short-term hypothyroidism. American Journal of Cardiology 1995 75 645-648. (doi:10.1016/S0002-9149(99)80641-9)

14 Monzani F, Di Bello V, Caraccio N, Bertini A, Giorgi D, Giusti C \& Ferrannini E. Effect of levothyroxine on cardiac function and structure in subclinical hypothyroidism: a double blind, placebocontrolled study. Journal of Clinical Endocrinology and Metabolism 200186 1110-1115. (doi:10.1210/jc.86.3.1110)

15 Vitale G, Galderisi M, Lupoli GA, Celentano A, Pietropaolo I, Parenti N, De Divitiis O \& Lupoli G. Left ventricular myocardial impairment in subclinical hypothyroidism assessed by a new ultrasound tool: pulsed tissue Doppler. Journal of Clinical Endocrinology and Metabolism 200287 4350-4355. (doi:10. 1210/jc.2002-011764)

16 Biondi B, Palmieri EA, Lombardi G \& Fazio S. Subclinical hypothyroidism and cardiac function. Thyroid 200212 505-510. (doi:10.1089/105072502760143890)

17 Yazici M, Gorgulu S, Sertbas Y, Erbilen E, Albayrak S, Yildiz O \& Uyan C. Effects of thyroxin therapy on cardiac function in patients with subclinical hypothyroidism: index of myocardial performance in the evaluation of left ventricular function. International Journal of Cardiology 200495 135-143. (doi:10.1016/j.ijcard. 2003.05.015)

18 Teichholz LE, Kreulen T, Herman MV \& Gorlin R. Problems in echocardiographic volume determinations: echocardiographicangiographic correlations in the presence of absence of asynergy. American Journal of Cardiology 197637 7-11. (doi:10.1016/ 0002-9149(76)90491-4)

19 Tei C, Ling LH, Hodge DO, Bailey KR, Oh JK, Rodeheffer RJ, Tajik AJ \& Seward JB. New index of combined systolic and diastolic myocardial performance: a simple and reproducible measure of cardiac function - a study in normals and dilated cardiomyopathy. Journal of Cardiology 199526 357-366.

20 Doin FL, Borges Mda R, Campos O, de Camargo Carvalho AC, de Paola AA, Paiva MG, Abucham J \& Moises VA. Effect of central hypothyroidism on Doppler-derived myocardial performance index. Journal of the American Society of Echocardiography 2004 17 622-629. (doi:10.1016/j.echo.2004.03.010)

21 Lavine SJ. Effect of heart rate and preload on index of myocardial performance in the normal and abnormal left ventricle. Journal of the American Society of Echocardiography 200518 133-141. (doi:10.1016/j.echo.2004.08.036)

22 Klein I \& Danzi S. Thyroid disease and the heart. Circulation 2007 116 1725-1735. (doi:10.1161/CIRCULATIONAHA.106.678326)

23 Buccino RA, Spann JF Jr, Pool PE, Sonnenblick EH \& Braunwald E. Influence of the thyroid state on the intrinsic contractile properties and energy stores of the myocardium. Journal of Clinical Investigation 196746 1669-1682. (doi:10.1172/JCI105658)

24 Timsit J, Riou B, Bertherat J, Wisnewsky C, Kato NS, Weisberg AS, Lubetzki J, Lecarpentier Y, Winegrad S \& Mercadier JJ. Effects of chronic growth hormone hypersecretion on intrinsic contractility, energetics, isomyosin pattern, and myosin adenosine triphosphatase activity of rat left ventricle. Journal of Clinical Investigation 199086 507-515. (doi:10.1172/JCI114737)

25 Ito H, Hiroe M, Hirata Y, Tsujino M, Adachi S, Shichiri M, Koike A, Nogami A \& Marumo F. Insulin-like growth factor-I induces hypertrophy with enhanced expression of muscle specific genes in cultured rat cardiomyocytes. Circulation 199387 1715-1721. (doi:10.1161/01.CIR.87.5.1715)

26 Delafontaine P. Insulin-like growth factor I and its binding proteins in the cardiovascular system. Cardiovascular Research 199530 825-834. (doi:10.1016/S0008-6363(95)00163-8)

27 Colao A. The GH-IGF-I axis and the cardiovascular system: clinical implications. Clinical Endocrinology 200869 347-358. (doi:10.1111/j.1365-2265.2008.03292.x)

28 Maison P \& Chanson P. Cardiac effects of growth hormone in adults with growth hormone deficiency: a meta-analysis. Circulation 2003108 2648-2652. (doi:10.1161/01.CIR. $0000100720.01867 .1 \mathrm{D})$

29 Behan LA, Monson JP \& Agha A. The interaction between growth hormone and the thyroid axis in hypopituitary patients. Clinical Endocrinology $2011 \mathbf{7 4}$ 281-288. (doi:10.1111/j.1365-2265. 2010.03815.x)

30 Portes ES, Oliveira JH, MacCagnan P \& Abucham J. Changes in serum thyroid hormones levels and their mechanisms during long-term growth hormone $(\mathrm{GH})$ replacement therapy in GH deficient children. Clinical Endocrinology 200053 183-189. (doi:10.1046/j.1365-2265.2000.01071.x)

31 Porretti S, Giavoli C, Ronchi C, Lombardi G, Zaccaria M, Valle D, Arosio M \& Beck-Peccoz P. Recombinant human GH replacement therapy and thyroid function in a large group of adult GH-deficient patients: when does L-T(4) therapy become mandatory? Journal of Clinical Endocrinology and Metabolism 200287 2042-2045. (doi:10.1210/jc.87.5.2042)

32 Agha A, Walker D, Perry L, Drake WM, Chew SL, Jenkins PJ, Grossman AB \& Monson JP. Unmasking of central hypothyroidism following growth hormone replacement in adult hypopituitary patients. Clinical Endocrinology $20076672-77$.

33 Martins MR, Doin FC, Komatsu WR, Barros-Neto TL, Moises VA \& Abucham J. Growth hormone replacement improves thyroxine biological effects: implications for management of central hypothyroidism. Journal of Clinical Endocrinology and Metabolism 200792 4144-4153. (doi:10.1210/jc.2007-0941)

34 Moller JE, Poulsen SH \& Egstrup K. Effect of preload alternations on a new Doppler echocardiographic index of combined systolic and diastolic performance. Journal of the American Society of Echocardiography 199912 1065-1072. (doi:10.1016/S0894-7317(99) 70103-3)

35 Spencer KT, Kirkpatrick JN, Mor-Avi V, Decara JM \& Lang RM. Age dependency of the Tei index of myocardial performance. Journal of the American Society of Echocardiography $2004 \quad 17$ 350-352. (doi:10.1016/j.echo.2004.01.003)

36 Rosen T \& Bengtsson BA. Premature mortality due to cardiovascular disease in hypopituitarism. Lancet 1990336 285-288. (doi:10.1016/0140-6736(90)91812-0)

37 Sherlock M, Ayuk J, Tomlinson JW, Toogood AA, AragonAlonso A, Sheppard MC, Bates AS \& Stewart PM. Mortality in patients with pituitary disease. Endocrine Reviews 201031 301-342. (doi:10.1210/er.2009-0033)

38 Rodondi N, den Elzen WP, Bauer DC, Cappola AR, Razvi S, Walsh JP, Asvold BO, Iervasi G, Imaizumi M, Collet TH, Bremner A, Maisonneuve P, Sgarbi JA, Khaw KT, Vanderpump MP, Newman AB, Cornuz J, Franklyn JA, Westendorp RG, Vittinghoff E \& Gussekloo J. Subclinical hypothyroidism and the risk of coronary heart disease and mortality. Journal of the American Medical Association 2010304 1365-1374. (doi:10.1001/jama.2010.1361)

Received 20 October 2011

Revised version received 21 December 2011

Accepted 20 January 2012 